\title{
Feasibility Study of 0.1 HP Nano Solar Pump with Gravity based Drip Irrigation System for Vegetable Cultivation
}

\author{
Dwarika Mohan Das ${ }^{1 *}$ and Rashmita Toppo ${ }^{2}$ \\ ${ }^{1}$ SWCE, CAET, OUAT, India \\ ${ }^{2}$ Horticulture, KVK Gajapati, OUAT, India \\ *Corresponding author
}

\section{A B S T R A C T}

K e y w o r d s
$\begin{aligned} & \text { Nano solar } \\ & \text { pump, } \\ & \text { gravity based } \\ & \text { drip irrigation }\end{aligned}$
Article Info
$\begin{aligned} & \text { Accepted: } \\ & \text { 25 May } 2018 \\ & \text { Available Online: } \\ & \text { 10 June } 2018\end{aligned}$

Keywords

Nano solar pump, gravity based drip irrigation

10 June 2018
Green revolution has made India self-sufficient in food grain production. In most of the state of India cereal production is a surplus. But cereal production is not improving the economical condition of farmers. Vegetable cultivation is however considered as 2-3 times profitable than traditional cereal cultivation. Farmers can make more profit by cultivating vegetable after cereal crops. But in Rabi and Zaid seasons irrigation water availability is a major problem in rainfed areas. Farmers generally use kerosene, diesel or electric power operated pumps for irrigation but operational cost of these pumps has become very high due to hike in unit price. Petroleum fuel operated pumps are also polluting the environment by releasing greenhouse gases. Therefore, solar pumps are now becoming popular among farmers for their zero operational cost. Drip irrigation is the most efficient method of irrigation till date and gravity based drip irrigation can save the cost of pumping. In this study nano solar pump with gravity based drip irrigation system has been evaluated for vegetable cultivation in the district Gajapati, Odisha and it is observed that the system is more profitable for Onion, Broccoli and Capsicum cultivation among ten remunerative vegetable crops of the study area.

\section{Introduction}

Water and energy are two basic needs for sustainability of a civilization. In the beginning of the $21^{\text {st }}$ century both energy and water have become costlier than before. Water availability for agriculture is also decreasing due to the increased demand from other sectors. Climate change is again creating uncertainty in water availability. On the other hand, due to rapid population growth agricultural lands are becoming more and more fragmented and smaller in size, which is leading to lower productivity. In India 67 percent of farmland is held by small and marginal farmers with land holdings below one hectare. These farmers get very low economic benefits from traditional farming practices. They have adopted mono cropping practice due to lack of irrigation after monsoon. In this situation, the traditional practices are unable to provide sufficient 
economic benefits to the small and marginal farmers to maintain their livelihood throughout the year. Therefore, the cropping intensity from these small and fragmented lands has to be increased with limited water and energy.

Generally, the percentage of small and marginal land holders is high in hilly terrain areas of India. In these places perennial streams are the main source of irrigation during Rabi and Zaid seasons. But their discharge decreases in post-monsoon seasons. Therefore, it has become very much challenging to use the stream water most efficiently to sustain farming during postmonsoon period in hilly areas. Drip irrigation is the most efficient system of irrigation having overall efficiency greater than 90 percent (Biswas et al., 2015; Sharma and Kumar, 2007). Gravity based drip irrigation system is most suitable for small and marginal farmers, because it does not need a big size pump for its operation, rather operated only by gravitational potential (Changade and Piwalatkar, 2010).

The traditional flow irrigation systems with diesel, kerosene or electric power operated pumps, are not at all economical in energy, water and cost economics points of view for small and marginal farmers (Smairan, 2012; Kamwamba et al., 2016). Petroleum fuel stock in earth is decreasing day by day, resulting rapid increase in fuel cost. Burning of these fuels is also creating environmental pollution by releasing green house gases to the atmosphere. Hence, the need of the hour is to develop such systems which must be sustainable and will not cause any damage to the environment. In this situation use of solar power for water pumping is best solution in the field of irrigation which does not create any environmental pollution and also needs negligible operational cost (Lopez-Luque et al., 2015; Mohammed et al., 2018). The initial cost of large size solar pumps is much higher than the traditional electric or diesel pumps. For small or marginal farmers, it is very difficult to afford for a high horse power solar pump (Xie et al., 2014). Therefore, small or nano size solar DC pumps are recommended for them (Schmitter et al., 2018). But, the farmers need to cultivate the most remunerative crop for getting higher net return and early payback of the initial investment. Among different crops, vegetable crops have the highest yield potential and can give 2-3 time higher profit than field crops (Pereira et al., 2015). However, a comparative study needs to be carried to identify the most suitable one among different types of vegetable crops which can give higher benefits to the farmers. Considering all these facts, feasibility study of a $0.1 \mathrm{HP}$ nano solar pump with gravity drip irrigation system has been taken up for vegetable cultivation in district Gajapati, Odisha, with an objective to select the most suitable vegetable crop and its area that can give higher return and early payback period.

\section{Materials and Methods}

\section{Study area}

The study was conducted at Krishi Vigyan Kendra Gajapati, situated in the central part of Gajapati district of the state Odisha, India, shown in fig. 1. District Gajapati is surrounded by North Eastern Ghat range of hills. It is a tribal dominated district having $54 \%$ tribal population. Around $91 \%$ of farmers in the district are small and marginal. The climate of the district is sub-tropical and subhumid. Irrigation is a major problem in the district during post-monsoon period. Perennial streams are main source of irrigation in the hilly terrains of the district. The climate of the district is very much suitable for horticultural crops but due to lack of irrigation the farmers have adopted mono cropping. Nano solar 
pump with gravity based drip irrigation system can enable the famers to lift water without any operating cost. The system has potential to produce three crops from a piece of land in a year and will be very much helpful towards doubling the income of small and marginal farmers.

\section{Nano solar pumping system}

Many emerging companies are now manufacturing small size solar pumps targeting the small and marginal land holders of the country. In this study, a nano solar pump manufactured by Jain Irrigation Systems Ltd., along with Sun Green Energy Corporation has been evaluated for vegetable cultivation at KrishiVigyan Kendra, Gajapati, Odisha. The nano pump is operated by $0.1 \mathrm{HP}$ solar DC output. It has average discharge of $500 \mathrm{l} / \mathrm{h}$, suction head and delivery head of $6 \mathrm{~m}$ and $30 \mathrm{~m}$, respectively. Its discharge can go up to $700 \mathrm{l} / \mathrm{h}$ during the peak solar insolation. It has two 40 watt solar panels. This pump can lift water from surface water sources within 7 $\mathrm{m}$ from pump level and can deliver water at an elevation of 30 meters from its level.

\section{Gravity based drip irrigation system}

Many micro-irrigation companies are now manufacturing gravity based drip kits for small size lands. In this system pump is not used to force water, rather potential head due to high elevation of water is used for dripper operation to meet the crop water requirement. Generally, a water tank is fixed at some elevation, which creates pressure for easy flow of water in the drip lines. Regulating valve and screen filter are fixed after the water tank. The system does not have any sand filter or hydro-cyclone filter; hence, clean water should be supplied into the tank to avoid clogging of the system. A farmer can use gravity based drip system for irrigating up to $2000 \mathrm{~m}^{2}$ area based on crop type and pump capacity. This irrigation system enables farmers for producing high value crops with less cost and energy input than traditional system.

\section{Gravity drip irrigation system with nano solar pump}

Nano solar pump with gravity based drip irrigation can save both energy and water. In this system, nano solar pump is used to lift water from water sources like stream, pond, well, tank etc., to an overhead tank constructed in the field. From the tank water flows in drip lines due to gravitational potential. Pressure in the drip system depends on the height of the overhead tank. The overhead should be placed at 4-5 m height from the ground surface for easy operation of the drip system (http://www.jains.com). Command area of the nano solar pump can be estimated based on the crop type, crop water requirement, and average discharge of the pump. The layout of the system is shown in fig.2.

\section{Crop area estimation}

The average discharge of nano solar pump is $500 \mathrm{l} / \mathrm{h}$. Area that can be sufficiently irrigated by the nano solar pump depends on crop type and per day discharge capacity of the pump. As, per day discharge of the pump is fixed, crop having lower water requirement can be cultivated in a larger area compared to crop having higher water requirement. Therefore, most remunerative crop should be selected among different high value crops, which can give better net return to the farmers and also help in quick payback of the initial investment. Crop area matching to the solar nano pump can be estimated by knowing the crop water requirement and crop duration (Pereira et al., 2015) and can be estimated using the equations (i), (ii) and (iii). 


$$
\begin{aligned}
& \text { Area irrigated per day }\left(\mathrm{m}^{2}\right)=\frac{\mathrm{Q}_{\mathrm{p}}}{\mathrm{Q}_{\mathrm{R}}} \times 10000 \text { (i) } \\
& \mathrm{Q}_{\mathrm{p}}=\mathrm{Q}_{\mathrm{av}} \times \text { AS } \\
& \mathrm{Q}_{\mathrm{R}}=\frac{\mathrm{CwR} \times 10000}{\mathrm{CP} \times 1000} \\
& \text { Where: } \\
& \mathrm{Q}_{\mathrm{p}}=\text { Daily water pumping capacity of solar pur } \\
& \mathrm{Q}_{\mathrm{R}}=\text { Daily crop water requirement per ha (I) } \\
& \mathrm{Q}_{\mathrm{av}}=\text { Average daily discharge of pump (l) } \\
& \mathrm{AS}=\text { Available Sunshine hours (h) } \\
& \mathrm{CP}=\text { Crop Period (days) } \\
& \mathrm{CWR}=\text { Crop water requirement for the crop period(mm) }
\end{aligned}
$$

\section{Cost economics}

The initial investment in nano solar pump with gravity based drip irrigation system is high compared to the traditional system of water pumping and irrigation, but the operational cost and percentage of water loss are less. Therefore, farmers should know the most femanterative crop, so that they will be able to choose the right crop for higher net income and early payback of the initial investment. Net return and payback period of the system is calculated using the equations iv, v, vi and vii.

$$
\begin{aligned}
& \text { Gross Income }(\mathrm{Rs} / \mathrm{ha})=\text { Yield }(\mathrm{q} / \mathrm{ha}) \times 100 \times \text { Selling Price }(\mathrm{Rs} / \mathrm{kg}) \\
& \text { Net Income }(\mathrm{Rs} / \mathrm{ha})=\text { Gross Income }(\mathrm{Rs} / \mathrm{ha})-\text { Cost of Cultivation(Rs/ha) } \\
& \text { Net Income }\left(\frac{\mathrm{Rs}}{\operatorname{Crop} \text { area }\left(\mathrm{m}^{2}\right)}\right)=\frac{\text { Net Income }(\mathrm{Rs} / \mathrm{ha})}{10000} \times \operatorname{Crop} \text { area }\left(\mathrm{m}^{2}\right) \\
& \text { Payback Period(years) }=\frac{\text { Cost of investement (Rs) }}{\text { Annual cash flow from the project (Rs) }}
\end{aligned}
$$

\section{Results and Discussion}

\section{Crop selection}

In this study ten locally cultivated vegetable crops, which can be grown successfully under drip irrigation were taken into consideration, shown in table 1 . These are also the most popular vegetable crops in the district Gajapati and also in Odisha. Most of the farmers generally cultivate these vegetables in post monsoon period.

These vegetables need relatively high amount of water than other field crops except rice. But the market value of these vegetables is higher than other crops due to less vegetable production in the district. Crop period and crop water requirement of the selected vegetable crops are also shown in table 1 . The data have been collected based on different field experiments and published literatures.

\section{Crop area estimation}

Selected vegetable crops have different crop duration and also crop water requirement as shown in table 1 . Hence, the daily crop water requirement will vary from crop to crop. But the nano solar pump has a fixed discharge of 500 litters per hour.

Taking four hours of available sunshine hours, daily water pumping capacity of the pump is 2000 litters. Therefore, area that can be irrigated by the pump will vary from crop to crop and has been calculated by equation (i) and the results are shown in table 2.

Table 2 indicates that Onion can be grown in $500 \mathrm{~m}^{2}$ area, which is highest among other crops and Okra can be grown in $300 \mathrm{~m}^{2}$ area, which is lowest among selected crops. This is due to the fact that Onion has lowest per day 
water requirement compared to other selected crops. The estimated area can be sufficiently irrigated by the solar nono-pump to meet the crop water requirement of respective crops.

\section{Cost of the system}

Initial investment in nano solar pump is higher than other pumps. Cost of drip irrigation depends on area under cultivation. But the system has negligible operational cost compared to traditional irrigation system. Cost of the nano solar-pump is fixed i.e., Rs. 18000 but the drip irrigation system costs Rs.20000 per acre. Hence, the system cost will vary for each crop, as per the area under cultivation, shown in table 2. Cost of nano solar pump with gravity based drip irrigation system for the estimated area of respective crops is shown in the table 3.

\section{Net return}

Based on previous demonstrations conducted by the KVK in the farmers' field, average yield, cost of cultivation, selling price, gross return and net return per hectare for the selected crops are known and shown in table 4.
The study revealed that highest net return can be achieved from Onion cultivation followed by Broccoli and Capsicum from the recommended area under nano solar pump and gravity based drip irrigation system, fig. 3 . Net return of less than Rs. 5000 was obtained from Okra, Chilli and Beans. This because of the combined effect of low yield, market price and recommended crop area, shown in tables 4 and 2. Validation of some the results has been carried out through field demonstrations and the result has shown close agreement between estimated and observed values.

\section{Payback period}

It is observed from different field experiments that vegetable cultivation under drip irrigation system generally gives 30 to 40 percent higher yield than the traditional system. In this study it is assumed that the farmer will only pay the extra amount of net return obtained from the higher yield towards payback of the initial investment. Hence, payback period is calculated considering $30 \%$ and $40 \%$ of the net return obtained from the selected vegetable crops as yearly return towards initial investment using eq. (vii), shown in fig. 4.

Table.1 Selected vegetable crops with crop period and crop water requirement

\begin{tabular}{|l|l|c|c|}
\hline SI. No. & \multicolumn{1}{|c|}{ Vegetables Crop } & Crop Duration(days) & Crop Water Requirement (mm) \\
\hline 1 & Tomato & 120 & 700 \\
\hline 2 & Capsicum & 150 & 750 \\
\hline 3 & Brinjal & 150 & 750 \\
\hline 4 & Cabbage & 120 & 650 \\
\hline 5 & Cauliflower & 120 & 700 \\
\hline 6 & Broccoli & 120 & 700 \\
\hline 7 & Onion & 150 & 600 \\
\hline 8 & Okra & 90 & 600 \\
\hline 9 & Chilli & 165 & 800 \\
\hline 10 & Beans & 90 & 500 \\
\hline
\end{tabular}


Table. 2 Estimated crop area matching to the daily discharge capacity of nano solar pump

\begin{tabular}{|l|l|c|c|c|}
\hline $\begin{array}{l}\text { SI. } \\
\text { No }\end{array}$ & Vegetable Crop & $\begin{array}{c}\text { Daily crop water } \\
\text { requirement }(\mathbf{m m})\end{array}$ & $\begin{array}{c}\text { Daily crop water } \\
\text { requirement per ha } \mathbf{( 1 )}\end{array}$ & $\begin{array}{c}\left.\text { Area irrigated per day } \mathbf{( m}^{2}\right) \\
\text { matching to the nano pump }\end{array}$ \\
\hline $\mathbf{1}$ & Tomato & 5.83 & 58333.33 & 342.86 \\
\hline $\mathbf{2}$ & Capsicum & 5.00 & 50000.00 & 400.00 \\
\hline $\mathbf{3}$ & Brinjal & 5.00 & 50000.00 & 400.00 \\
\hline $\mathbf{4}$ & Cabbage & 5.42 & 54166.67 & 369.23 \\
\hline $\mathbf{5}$ & Cauliflower & 5.83 & 58333.33 & 342.86 \\
\hline $\mathbf{6}$ & Broccoli & 5.83 & 58333.33 & 342.86 \\
\hline $\mathbf{7}$ & Onion & 4.00 & 40000.00 & 300.00 \\
\hline $\mathbf{8}$ & Okra & 6.67 & 66666.67 & 412.50 \\
\hline $\mathbf{9}$ & Chilli & 4.85 & 48484.85 & 360.00 \\
\hline $\mathbf{1 0}$ & Beans & 5.56 & 55555.56 & \\
\hline
\end{tabular}

Table.3 Cost of nano solar pump with gravity based drip system for selected crop area

\begin{tabular}{|l|l|c|c|}
\hline $\begin{array}{l}\text { S. } \\
\text { No. }\end{array}$ & $\begin{array}{l}\text { Vegetable } \\
\text { Crop }\end{array}$ & $\begin{array}{c}\text { Area irrigated per day } \\
\left(\mathbf{m}^{2}\right)\end{array}$ & $\begin{array}{c}* \text { Cost of Nano Solar pump+Drip } \\
\text { (Rs.) }\end{array}$ \\
\hline $\mathbf{1}$ & Tomato & 342.86 & 19714.29 \\
\hline $\mathbf{2}$ & Capsicum & 400.00 & 20000.00 \\
\hline $\mathbf{3}$ & Brinjal & 400.00 & 20000.00 \\
\hline $\mathbf{4}$ & Cabbage & 369.23 & 19846.15 \\
\hline $\mathbf{5}$ & Cauliflower & 342.86 & 19714.29 \\
\hline $\mathbf{6}$ & Broccoli & 342.86 & 19714.29 \\
\hline $\mathbf{7}$ & Onion & 500.00 & 20500.00 \\
\hline $\mathbf{8}$ & Okra & 300.00 & 19500.00 \\
\hline $\mathbf{9}$ & Chilli & 412.50 & 20062.50 \\
\hline $\mathbf{1 0}$ & Beans & 360.00 & 19800.00 \\
\hline
\end{tabular}

*Cost does not include any government subsidy

Table.4 Yield and cost economics of selected crops

\begin{tabular}{|l|l|l|c|c|c|c|}
\hline $\begin{array}{l}\text { S.. } \\
\text { No. }\end{array}$ & Vegetable Crop & $\begin{array}{c}\text { Average } \\
\text { Yield } \\
\text { (q/ha) }\end{array}$ & $\begin{array}{c}\text { Minimum } \\
\text { selling Price } \\
\text { (Rs/kg) }\end{array}$ & $\begin{array}{c}\text { Gross return } \\
\text { (Rs/ha) }\end{array}$ & $\begin{array}{c}\text { Cost of } \\
\text { cultivation } \\
\text { (Rs/ha) }\end{array}$ & $\begin{array}{c}\text { Net Return } \\
\text { (Rs/ha) }\end{array}$ \\
\hline $\mathbf{1}$ & Tomato & 450 & 5 & 225000 & 61000 & 164000 \\
\hline $\mathbf{2}$ & Capsicum & 180 & 15 & 270000 & 72000 & 198000 \\
\hline $\mathbf{3}$ & Brinjal & 350 & 5 & 175000 & 58000 & 117000 \\
\hline $\mathbf{4}$ & Cabbage & 450 & 5 & 225000 & 56000 & 169000 \\
\hline $\mathbf{5}$ & Cauliflower & 230 & 10 & 230000 & 56000 & 174000 \\
\hline $\mathbf{6}$ & Broccoli & 125 & 25 & 312500 & 66000 & 246500 \\
\hline $\mathbf{7}$ & Onion & 300 & 10 & 300000 & 65000 & 235000 \\
\hline $\mathbf{8}$ & Okra & 150 & 10 & 150000 & 45000 & 105000 \\
\hline $\mathbf{9}$ & Chilli & 130 & 10 & 130000 & 48000 & 82000 \\
\hline $\mathbf{1 0}$ & Beans & 125 & 10 & 125000 & 57000 & 68000 \\
\hline
\end{tabular}


Fig.1 Study area

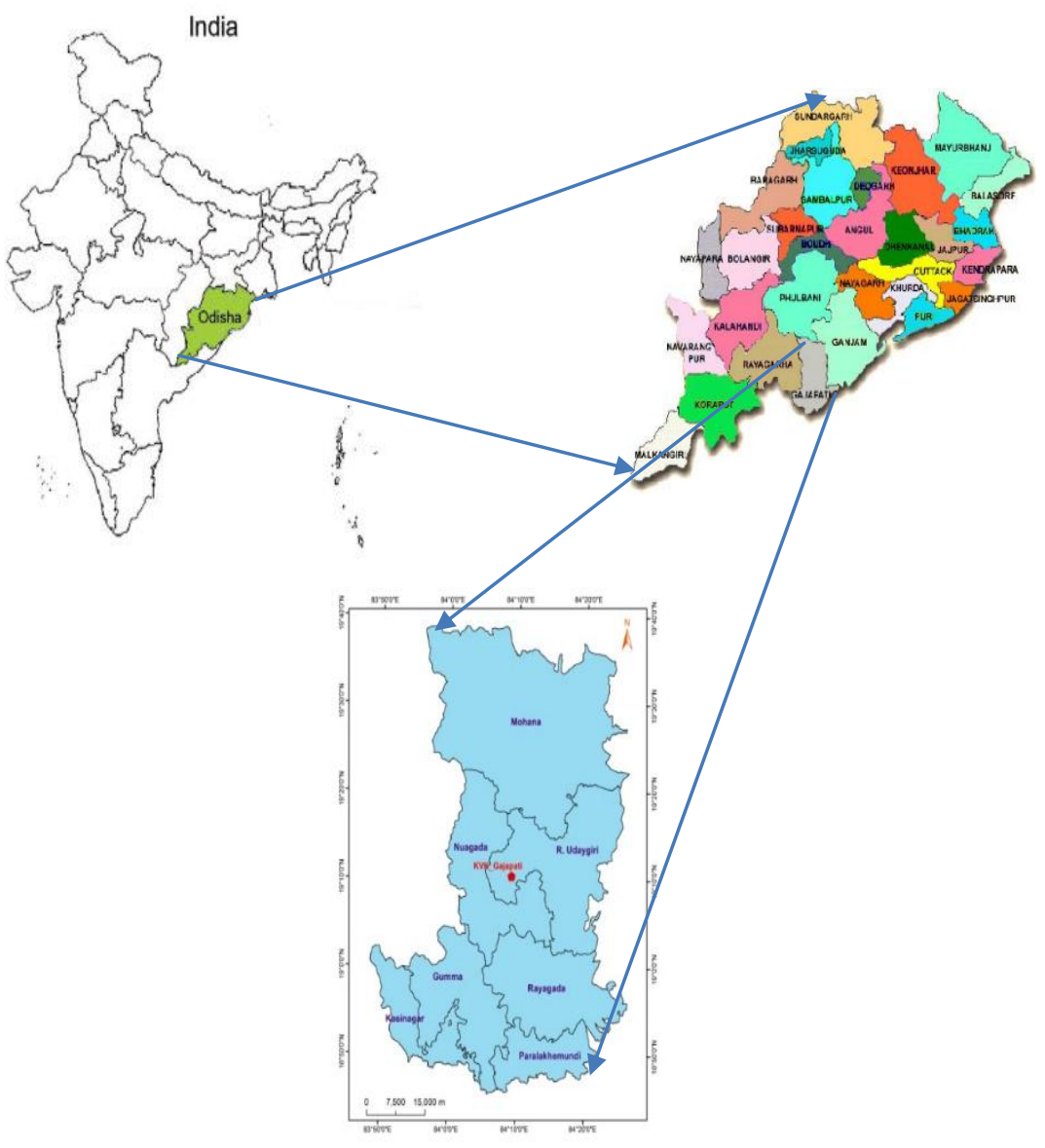

Fig.2 Schematic diagram of nano solarpump with gravity based drip irrigation system

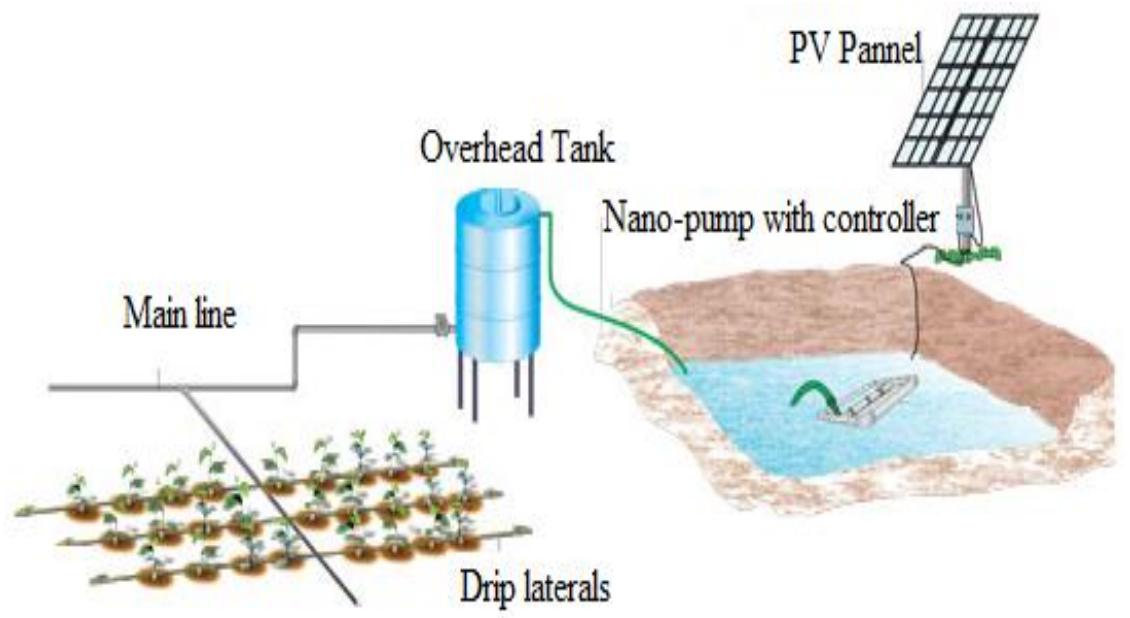

(Source: $\underline{\text { http://www.jains.com/) }}$ 
Fig.3 Net return from selected crops

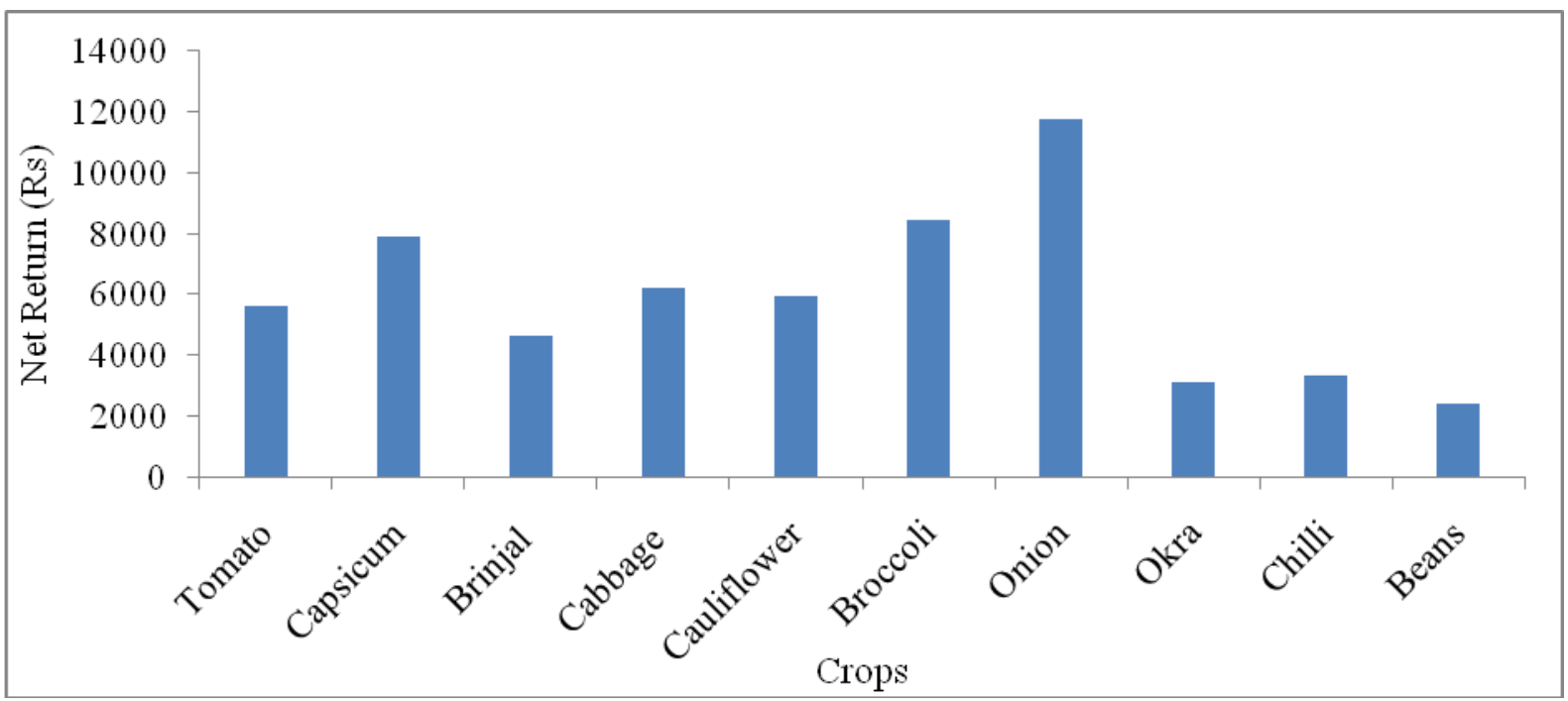

Fig.4 Payback period of nano solar pump with drip irrigation under selected crops

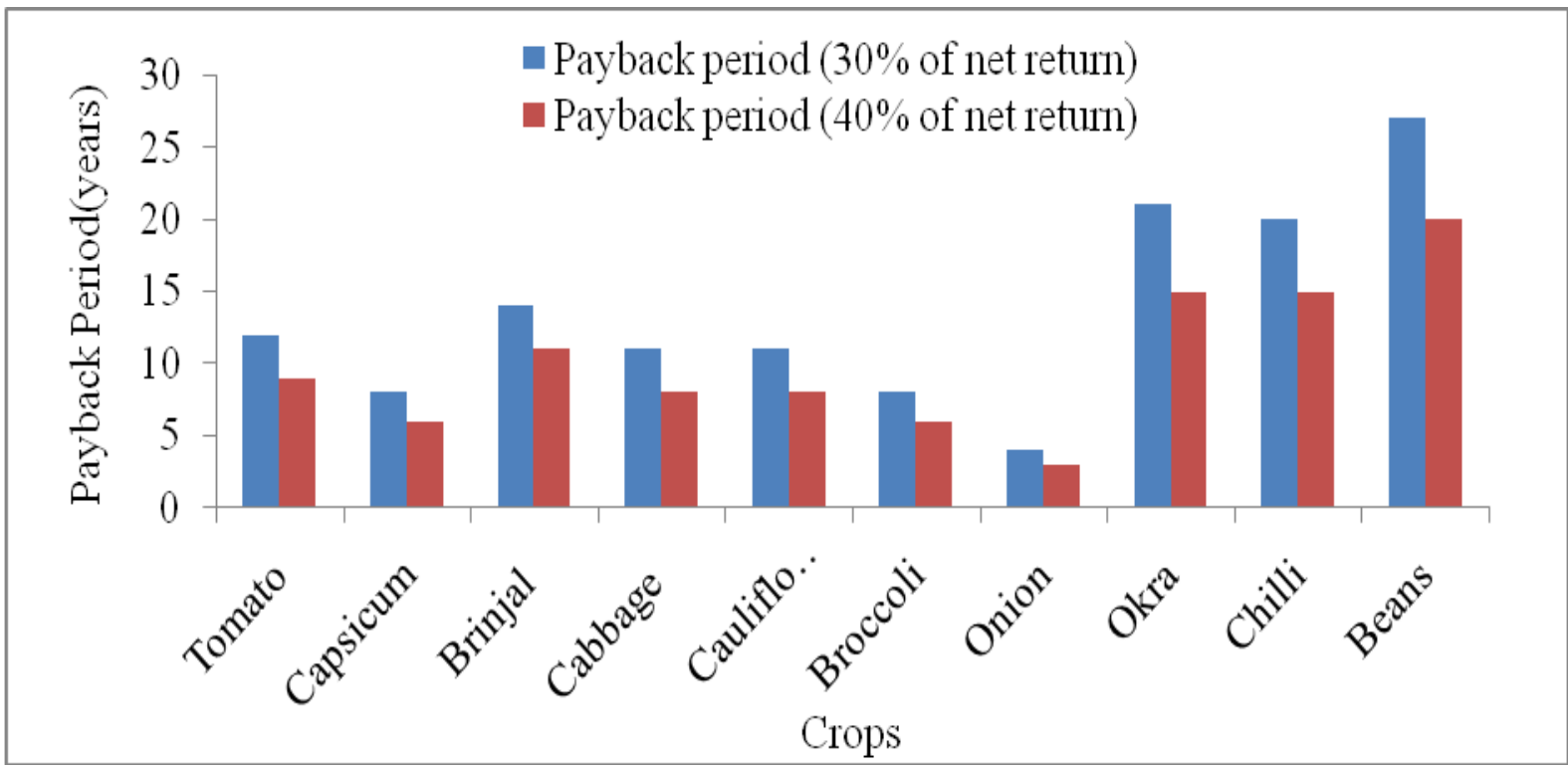

The study also revealed that Onion has lowest payback period among other crops followed by Broccoli and Capsicum, fig.4. The nano solar pump has an average life of 15 years. Therefore, crops like Okra, Chilli and Beans showing payback period above 15years should not be cultivated under this system with the prevailing market price. Only Onion, Capsicum and Broccoli having payback period close to 5 years are recommended for cultivation under nano solar pump with gravity based drip irrigation system for early return of the initial investment.

It is concluded that the study has been conducted with an objective to recommend suitable crops out of ten remunerative vegetable crops to the farmers which can be profitably grown under nano solar pump with gravity based drip irrigation system. 
Maximum area under cultivation that can be sufficiently irrigated using nano solar pump and gravity based drip irrigation system has been estimated for the ten selected crops. This will help framers to know the exact area under cultivation for different crops using the nano solar pump for irrigation. Among the selected vegetable crops highest net return and less payback period are obtained from Onion cultivation followed by Broccoli and Capsicum. Hence, farmer are recommended to choose any of these three crops based on the market demand for cultivating under nano solar pump and gravity based drip irrigation system for better net return and early payback of the initial investment.

\section{References}

Biswas, S. K., Akanda, A. R., Rahman, M.S., and Hossain, M. A., (2015). Effect of drip irrigation and mulching on yield, water-use efficiency and economics of tomato Plant. Soil Environ., 61 (3): 97102.

Changade, N. M. and Piwalatkar, G. K., (2010). Design of gravity-fed drip irrigation system for tree based farming system, Int. J. of Agric. Engg., 2 (2): 249-253.

http://www.jains.com

Kamwamba, M. J., Weatherhead, K., and Knox, J., (2016). Assessing performance of small-scale pumped irrigation systems in sub-Saharan Africa: Evidence from a systematic review. Irrigat. and Drain., 65(3): 308318.
Lopez-Luque, R., Reca, J., and Martinez, J., (2015). Optimal design of a standalone direct pumping photovoltaic system for deficit irrigation of olive orchards. Applied Energy, 149:13-23.

Mohammed, W. S., Hughes, B. R., O'Connor, D., and Kaiser C. J., (2018). A review of sustainable solar irrigation systems for Sub-Saharan Africa. Renew. Sustain. Energy Rev., 81:1206-1225.

Pereira, L.S., Allen, R.G., Smith, M., and Raes, D., (2015). Crop evapotranspiration estimation with FAO56: Past and future. Agric.Water Manage., 147: 4-20.

Schmitter, P., Kibret, K. S., Lefored, N., and Barron, J., (2018). Suitability mapping framework for solar photovoltaic pumps for smallholder farmers in sub-Saharan Africa. Applied Geography., 94: 41-57.

Sharma, I. P. and Kumar, P., (2007). Effect of drip irrigation and $\mathrm{N}$ and $\mathrm{P}$ application on soil moisture distribution and water use efficiency of charysanthemum (Dendranthema grandiflorum) in inceptsols. Indian J. Soil Cons., 35 (1): 50-53.

Smairan, M., (2012). Application of photovoltaic array for pumping water as an alternative to diesel engines in Jordan Badia, Tall Hassan station: case study. Renew. Sustain. Energy Rev., 16 (7): 4500-4507.

Xie, H., You, L., Wielgosz, B., and Ringler, C. (2014). Estimating the potential for expanding small holder irrigation in Sub-Saharan Africa. Agric.Water Manage., 131(0):183-193.

\section{How to cite this article:}

Dwarika Mohan Das and Rashmita Toppo. 2018. Feasibility Study of 0.1 HP Nano solar Pump with Gravity based Drip Irrigation System for Vegetable Cultivation. Int.J.Curr.Microbiol.App.Sci. 7(06): 3825-3833. doi: https://doi.org/10.20546/ijcmas.2018.706.450 